\title{
Selection of Streptomyces against soil borne fungal pathogens by a standardized dual culture assay and evaluation of their effects on seed germination and plant growth
}

\author{
Andrea Kunova $^{* \dagger} \mathbb{D}$, Maria Bonaldi ${ }^{\dagger}$, Marco Saracchi, Cristina Pizzatti, Xiaoyulong Chen and Paolo Cortesi
}

\begin{abstract}
Background: In the search for new natural resources for crop protection, streptomycetes are gaining interest in agriculture as plant growth promoting bacteria and/or biological control agents. Because of their peculiar life cycle, in which the production of secondary metabolites is synchronized with the development of aerial hyphae and sporulation, the commonly used methods to screen for bacterial antagonists need to be adapted.

Results: The dual culture assay was standardized in terms of inoculation timing of Streptomyces antagonist and pathogen, and growth rate of different fungal pathogens. In case of fast-growing fungi, inoculation of the antagonist 2 or 3 days prior to the pathogen resulted in significantly stronger inhibition of mycelium growth. One hundred and thirty Streptomyces strains were evaluated against six destructive soil borne pathogens. The activity of strains varied from broad-spectrum to highly specific inhibition of individual pathogens. All strains inhibited at least one tested pathogen. Three strains, which combined the largest broad-spectrum with the highest inhibition activity, were selected for further characterization with four vegetable species. All of them were able to colonize seed surface of all tested vegetable crops. They mostly improved radicle and hypocotyl growth in vitro, although no statistically significant enhancement of biomass weight was observed in vivo. Occasionally, transient negative effects on germination and plant growth were observed.

Conclusions: The adapted dual culture assay allowed us to compare the inhibition of individual Streptomyces strains against six fungal soil borne pathogens. The best selected strains were able to colonize the four vegetable crops and have a potential to be developed into biocontrol products. Although they occasionally negatively influenced plant growth, these effects did not persist during the further development. Additional in vivo studies are needed to confirm their potential as biological control or plant growth promoting agents.
\end{abstract}

Keywords: Dual culture assay, Antagonism, Antibiosis, Biological control, Seed colonization, Plant growth promotion

\section{Background}

Modern agricultural systems aim to ensure sustainable crop production and thus they drive the search for new natural resources to find environmentally friendly solutions for crop protection and yield increase. As a part of this research, streptomycetes, a group of Gram-positive,

\footnotetext{
*Correspondence: andrea.kunova@unimi.it

${ }^{\dagger}$ Equal contributors

Department of Food, Environmental and Nutritional Sciences (DeFENS),

Università degli Studi di Milano, via Giovanni Celoria, 2, 20133 Milan, Italy
}

mycelium-forming bacteria are gaining interest in agriculture as plant growth promoting bacteria (PGPB) and/ or biological control agents (BCAs). The genus Streptomyces comprises more than 500 species ubiquitous in nature, which can be free-living in soil or symbionts of eukaryotic organisms, ranging from fungi to plants, insects and marine animals (reviewed in [1]). Few Streptomyces species are pathogens of tuberous and taproot crops causing economically important diseases [2], and very little is known about the effects of other species on 
plant growth and health. Some streptomycetes are able to colonize plant rhizosphere and live as endophytes in the roots of numerous crops [3-6]. Occasional reports demonstrated that Streptomyces species were able to suppress plant pathogens, and some of them promoted plant growth $[7,8]$. They protected plant roots by inhibiting fungal pathogens through the production of lytic enzymes and antifungal compounds [9-13]. Local and systemic activation of plant defense systems through induced or acquired resistance by Streptomyces was described, in which they primed the defense pathways by inducing low-level expression of systemic acquired resistance and jasmonate/ethylene pathways [14-16]. Furthermore, plant growth promotion was observed through the auxin or siderophore production. Positive effects of Streptomyces application on seed germination and on root and shoot growth were reported [17-23]. These observations, the ability of Streptomyces to produce a huge variety of antimicrobial secondary products [24] and their presence in soil make them promising candidates for the selection and development as plant protection products and biofertilizers.

The selection of biological control agents usually starts with an in vitro screening of a collection of strains against selected pathogens by a dual culture assay, in which the candidate BCA is co-cultivated with the pathogen on agar medium and its antagonistic activity is quantified in terms of inhibition of pathogen's mycelium growth [25]. The production of many secondary metabolites in Streptomyces is induced upon the development of aerial hyphae and the beginning of sporulation [2628]. However, this developmental peculiarity was not always considered in previous studies, where the inoculation timing of the Streptomyces strains varied from inoculating Streptomyces 7 days before the pathogen to the co-inoculation at the same day [29-32]. Moreover, the growth rate of different pathogens was also not taken into consideration. Therefore, there is a strong need for a standardized methodology that would consider the particular life cycle of Streptomyces antagonists and growth rate of different fungal pathogens. This will help to reduce the risk of producing biased results when screening a large pool of streptomycetes against a variety of fungal pathogens. Similarly to the biocontrol studies, the selection of PGP strains involves in vitro screening for compounds such as phytohormones and siderophores, followed by in vivo evaluation of their activity [32-34]. Diverse Streptomyces spp. were shown to produce PGP related metabolites and enhance plant growth through phosphate solubilization, iron chelation, and auxin production [22, 35-37]. Indeed, positive effects of streptomycete application on seed germination, root growth, as well as hypocotyl development were observed [17-21, 23].
Biological control and PGP are two different but linked components associated with beneficial plantmicrobe interactions [38], and can share the same molecular mechanisms. For instance, some fungal pathogens require iron for their pathogenicity [39]. On the other hand, siderophores produced by beneficial rhizobacteria are responsible for scavenging ferric iron from the environment and may directly inhibit the pathogen growth by iron competition [40]. At the same time, they make the iron available for plant growth and may serve as inducers of plant systemic resistance [34, 41, 42]. Sometimes, negative effects of streptomycetes on plant growth were also observed, e.g., some Streptomyces strains adversely influenced the growth of monocotyledonous and dicotyledonous plants [43, 44]. Therefore, evaluating effects of streptomycetes on plant growth in absence of pathogen is an important step in developing Streptomyces-based biocontrol products.

The objectives of this work were, 1) to standardize the dual culture assay considering the inoculation timing of Streptomyces and the pathogen growth rate, 2) to evaluate the standardized method by screening the antagonism of 130 root endophytic streptomycetes against six common and destructive soil borne fungal pathogens of vegetable crops, and 3) to evaluate the effects of three most active streptomycete strains on seed germination and growth of four vegetable crops.

\section{Results \\ Mycelium growth rate of selected soil borne fungal pathogens}

The growth curves of the six soil borne fungal pathogens were determined on CZY medium: Sclerotinia sclerotiorum FW361, Rhizoctonia solani FW408, Fusarium oxysporum f.sp. lactucae L74, Pythium ultimum FW407, Phytophthora sp. FW409 and Thielaviopsis basicola FW406 (Fig. 1). Based on their growth rate, they were divided into three groups: 1 . fast-growing, 2. mediumgrowing, and 3. slow-growing. The group 1 comprised $S$. sclerotiorum FW361 and R. solani FW408; their colonies reached the edges of the $90 \mathrm{~mm}$ Petri plates 4 days after the inoculation. F. oxysporum f.sp. lactucae L74 and $P$. ultimum FW407 grew slightly slower: 4 days after inoculation, their mean radial growth was 17.5 and $18.1 \mathrm{~mm}$, respectively and were classified as group 2 . The group 3 included Phytophthora sp. FW409 and T. basicola FW406, which grew very slowly; 4 days after the inoculation their mean radial growth was 10.6 and $12.2 \mathrm{~mm}$, respectively.

\section{Optimization of the dual culture assay}

The dual culture assay was optimized to be able to compare the inhibition activity of 130 Streptomyces strains against six soil borne fungal pathogens belonging to the 


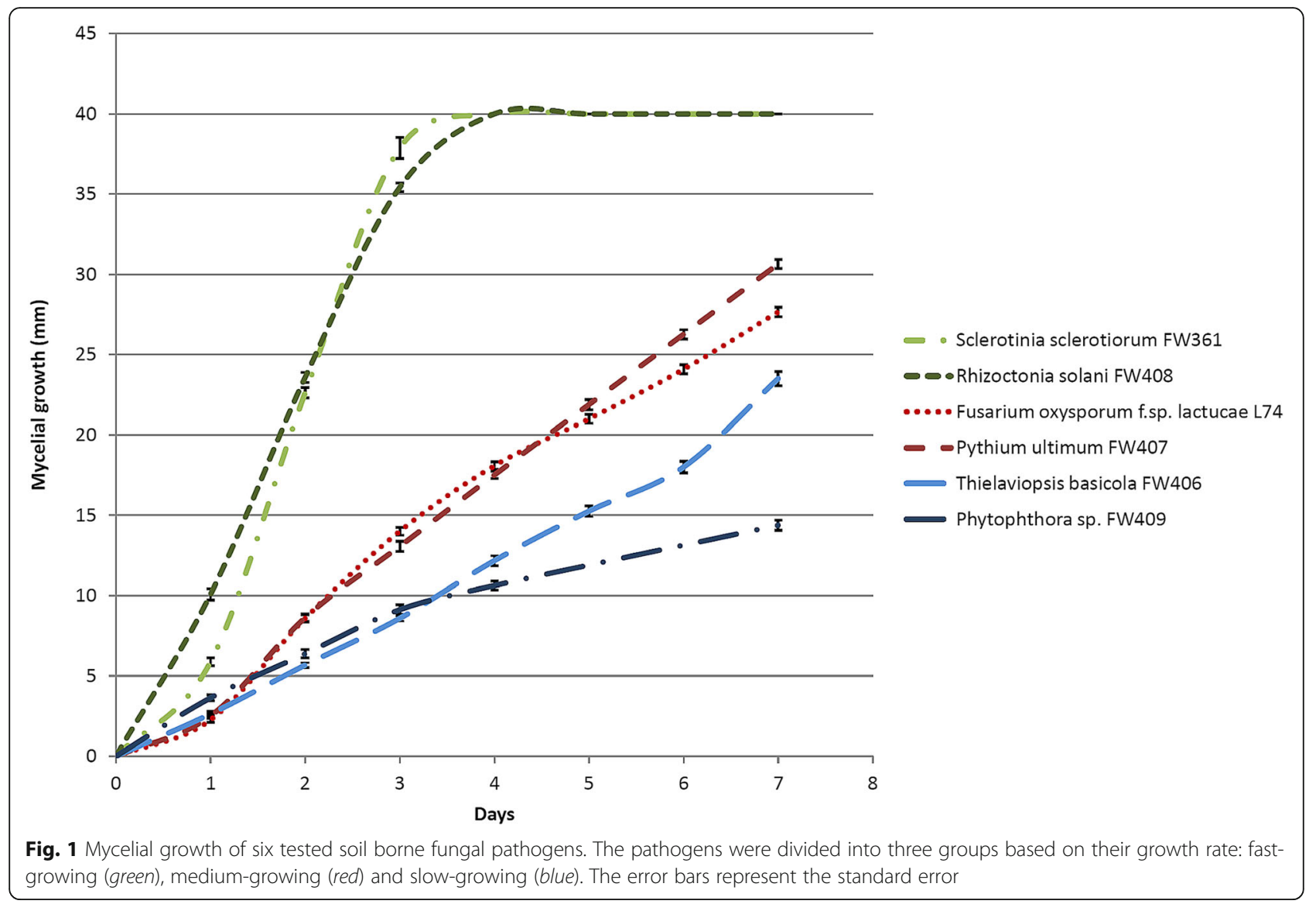

Table 1 Inhibition of pathogen mycelium growth based on timing of Streptomyces inoculation

\begin{tabular}{|c|c|c|c|c|}
\hline & & \multirow{2}{*}{$\begin{array}{l}\text { Day of } \\
\text { Streptomyces } \\
\text { inoculation }^{\text {a }}\end{array}$} & \multicolumn{2}{|c|}{ Mycelium growth inhibition (\%) } \\
\hline & & & $\begin{array}{l}\text { Sclerotinia } \\
\text { sclerotiorum } \\
\text { FW361 }\end{array}$ & $\begin{array}{l}\text { Fusarium } \\
\text { Oxysporum f. sp. } \\
\text { lactucae L74 }\end{array}$ \\
\hline \multirow{8}{*}{$\begin{array}{l}\text { Streptomyces } \\
\text { strain }\end{array}$} & \multirow[t]{4}{*}{ CMJ57I } & 0 & $58.43^{b} b^{c}$ & $56.06 \mathrm{a}$ \\
\hline & & -1 & $67.12 b$ & $56.06 a$ \\
\hline & & -2 & $77.35 \mathrm{a}$ & $58.82 \mathrm{a}$ \\
\hline & & -3 & 80.99 a & $56.06 \mathrm{a}$ \\
\hline & \multirow[t]{4}{*}{ CX14W } & 0 & $63.50 \mathrm{~b}$ & $59.41 \mathrm{a}$ \\
\hline & & -1 & $71.61 a b$ & $55.71 \mathrm{a}$ \\
\hline & & -2 & $74.65 \mathrm{a}$ & $55.88 \mathrm{a}$ \\
\hline & & -3 & $74.57 \mathrm{a}$ & 60.29 a \\
\hline
\end{tabular}

${ }^{a}$ Day 0 refers to the co-inoculation of the pathogen and Streptomyces, Days $-1,-2$ and -3 correspond to inoculation of Streptomyces 1,2 or 3 days before the pathogen

${ }^{\mathrm{b}}$ mean value of mycelium growth inhibition

' Tukey post-hoc test; mean values in a column with the same letters are not significantly different $(P=0.05)$ three groups based on their mycelium growth rate. We standardized the inoculation timing of pathogen and Streptomyces and the distance between the microorganisms. First, the inoculation timing of the two microorganisms was investigated. Two Streptomyces reference strains (S. rochei CMJ57I and S. anulatus CX14W) were inoculated 3, 2 or 1 day before or at the same day as $S$. sclerotiorum FW361 (group 1) or F. oxysporum f.sp. lactucae L74 (group 2) and the inhibition of pathogen mycelium growth was assessed 3 and 7 days after pathogen inoculation, respectively. In case of $S$. sclerotiorum FW361, when Streptomyces was inoculated 2 or 3 days before the pathogen, it caused significantly stronger inhibition of mycelium growth, while for $F$. oxysporum f.sp. lactucae L74 the inhibition of mycelium growth was not significantly different regardless the timing of streptomycete inoculation (Table 1). Next, to be able to compare the effect of the antagonists on fast- and slowgrowing fungi, the distance between the two microorganisms was set as the mean of the 4-day-mycelial growth for the pathogens of the groups 2 and 3; $20 \mathrm{~mm}$ and $10 \mathrm{~mm}$ respectively; and the antagonist and the pathogen were inoculated the same day. The pathogens of group 1 were inoculated 2 days after the antagonist to allow the production of bio-active compounds by 
streptomycetes and were placed in the distance corresponding to 2-day-mycelial growth $(25 \mathrm{~mm})$. The inhibition of mycelial growth was assessed 3 days after pathogen inoculation for fungi in the group 1, and 6 and 7 days after inoculation for fungi in groups 2 and 3 , respectively.

\section{Selection of streptomycetes based on their antagonistic activity}

After the optimization of the dual culture assay, the antagonistic activity of 130 Streptomyces strains was evaluated. They showed a wide range of inhibition activity against individual pathogens (Additional file 1: Table S1). The activity against S. sclerotiorum FW431 ranged from 0 to $87 \%$, with Streptomyces sp. ALP07R being the most active strain. The activity against $R$. solani FW408 was lower and varied from 0 to $72.4 \%$, with Streptomyces sp. SLF27R being the best strain. F. oxysporum f.sp. lactucae L74 was the least inhibited pathogen: Streptomyces sp. SLF27R, the most active strain, inhibited its growth by $47.9 \%$; and 15 out of 130 strains did not show any activity against this pathogen. The activity against P. ultimum FW407 varied from 0 to $63.64 \%$ and Streptomyces sp. CX08W was the best strain. Similarly, Streptomyces sp. MR01W was the most active against $T$. basicola FW406 and Phytophthora sp. FW409, with inhibition activity of 85.7 and $67.4 \%$, respectively. The mean rank values were calculated for each Streptomyces strain as described in Materials and Methods and the first three strains were chosen for further studies: $S$. cyaneus ZEA17I, S. anulatus CMJ58I and S. albidoflavus VT111I (Table 2). S. cyaneus ZEA17I was the most active strain: it strongly inhibited especially S. sclerotiorum FW431 (79.5 \%) and R. solani FW408 (67.5 \%). S. anulatus CMJ58I was very active against $T$. basicola FW406 (76.2 \%), P. ultimum FW407 (57.4 \%) and Phytophthora sp. FW409 (74.4 \%). Also S. albidoflavus VT111I resulted very active against P. ultimum FW407 (55.9 \%), but not against Phytophthora sp. FW409 (26.0 \%)

\section{Scanning electron microscope (SEM) studies of streptomycete seed colonization}

Prior to evaluating the PGP activity of the three selected Streptomyces strains, the colonization of seed surface of lettuce, lamb lettuce, rocket and tomato was examined by SEM. The observations confirmed that seed surfaces of all tested vegetable crops, previously inoculated with streptomycetes, were successfully colonized. The hyphae of Streptomyces strains were observed as early as $24 \mathrm{~h}$ post inoculation (hpi), and $72 \mathrm{hpi}$ seed surface was abundantly colonized (Fig. 2). Untreated seeds did not show any colonization (data not shown).

\section{Seed germination}

The germination of seeds of cultivated rocket, lamb lettuce, lettuce and tomato inoculated with $S$. cyaneus ZEA17I, S. anulatus CMJ58I and S. albidoflavus VT111I was assessed both in vitro and in vivo (Table 3 ). No differences in germination were observed in vitro, while some differences were observed in vivo. The selected strains did not show any negative effects on germination of cultivated rocket and lettuce. However, the germination of lamb lettuce was significantly inhibited after the bacterization with S. albidoflavus VT111I (33.0\%) compared to untreated control (64.0\%). Similarly, inhibition of tomato germination was observed after the treatment with S. cyaneus ZEA17I (88.3\%) compared to untreated control $(96.0 \%)$.

\section{Seedling root and hypocotyl length}

The root and hypocotyl lengths of seedlings grown in vitro varied depending on the combination vegetable crop - streptomycete strain (Table 4). All three strains significantly promoted the growth of radicles and hypocotyls of cultivated rocket and tomato and the radicles of lamb lettuce; e.g. S. anulatus CMJ58I augmented radicle growth of cultivated rocket ca. three-times (46.83 $\mathrm{mm}$ compared to $15.52 \mathrm{~mm}$ in untreated control). Moreover, S. anulatus CMJ58I promoted also the growth of lamb lettuce hypocotyls by ca. $30 \%$ and S. cyaneus ZEA17I significantly enhanced hypocotyl growth of lettuce (3.51 mm compared to $2.97 \mathrm{~mm}$ in untreated control). However, in lamb lettuce, S. albidoflavus VT111I and $S$. cyaneus ZEA17I negatively affected the radicle growth by 35 and $46 \%$ respectively; and S. cyaneus ZEA17I also significantly reduced hypocotyl length by $18 \%$.

Table 2 Mycelial growth inhibition of six fungal soil borne pathogens by Streptomyces cyaneus ZEA17I, S.anulatus CMJ58I and S. albidoflavus VT111I and their respective mean rank positions following dual culture assay

\begin{tabular}{|c|c|c|c|c|c|c|c|}
\hline \multirow{2}{*}{$\begin{array}{l}\text { Streptomyces } \\
\text { sp. }\end{array}$} & \multirow{2}{*}{$\begin{array}{l}\text { Mean } \\
\text { rank } \\
\text { position }\end{array}$} & \multicolumn{6}{|c|}{ Mycelium growth inhibition (\%) } \\
\hline & & $\begin{array}{l}\text { Sclerotinia } \\
\text { sclerotiorum FW361 }\end{array}$ & $\begin{array}{l}\text { Rhizoctonia } \\
\text { solani FW408 }\end{array}$ & $\begin{array}{l}\text { Fusarium oxysporum f.sp. } \\
\text { lattucae L74 }\end{array}$ & $\begin{array}{l}\text { Thielaviopsis } \\
\text { basicola FW406 }\end{array}$ & $\begin{array}{l}\text { Pythium ultimum } \\
\text { FW407 }\end{array}$ & $\begin{array}{l}\text { Phytophtora sp. } \\
\text { FW409 }\end{array}$ \\
\hline ZEA17I & 12.0 & 79.49 & 67.54 & 34.06 & 51.79 & 50.74 & 62.00 \\
\hline CMJ581 & 21.8 & 46.79 & 41.75 & 28.99 & 76.19 & 57.35 & 74.42 \\
\hline VT111I & 27.3 & 64.10 & 53.95 & 28.47 & 52.38 & 55.88 & 26.00 \\
\hline
\end{tabular}




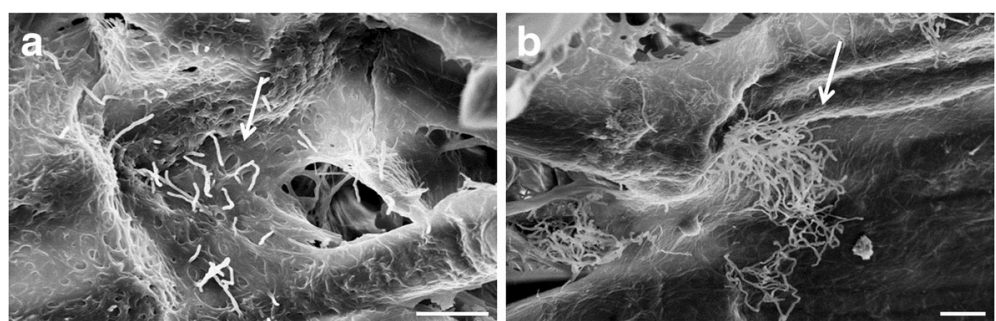

Fig. 2 Scanning electron microscopy micrographs of tomato seed surface $24 \mathrm{~h} \mathrm{(a)}$ and $72 \mathrm{~h}$ (b) after inoculation with Streptomyces albidoflavus VT111l. Arrows indicate the hyphae and the mycelium of S. albidoflavus VT1111. Bar equals to $10 \mu \mathrm{m}$

\section{Biomass dry weight in vivo}

The strain-specific effects on plant biomass of four vegetable crops were observed also in vivo in controlled conditions (Table 5). No significant differences were observed among biomass dry weight of any vegetable crop, when the three strains were compared to control. Interestingly, S. cyaneus ZEA17I increased the dry weight of 2-week-old tomatoes compared to S. anulatus CMJ58I and S. albidoflavus VT111I. Instead, in 3-week-old lettuce, S. anulatus CMJ58I showed negative effect on biomass compared to S. cyaneus ZEA17I and S. albidoflavus VT111I.

\section{Production of secondary metabolites}

All three tested strains produced indole-3-acetic acid. The highest amount was produced by Streptomyces anulatus CMJ58I (4.25 $\mu \mathrm{g} / \mathrm{mL}$, s.e. 0.063), whereas S. cyaneus ZEA17I and S. albidoflavus VT111I produced $3.71 \mu \mathrm{g} / \mathrm{mL}$ (s.e. 0.17) and $3.26 \mu \mathrm{g} / \mathrm{mL}$ (s.e. 0.16), respectively. None of the strains produced siderophores.

\section{Discussion}

Over the years, diverse bacteria - such as Pseudomonas spp. and Bacillus spp. - have been tested as BCAs, mostly studying the antagonism as the mechanism of action to suppress pathogen growth through the production of antifungal compounds [40, 45]. Recently, another group - streptomycetes - are of interest in agriculture as PGPB and BCAs, as they are commonly found in soil and are able to colonize rhizosphere and root tissues [3, $33,46]$. They surely have the potential to act as antagonists against a variety of soil borne pathogens, as they are renowned for the production of bioactive secondary metabolites. However, until now they have been exploited mostly in pharmaceutical industry for the production of antibiotics, antitumorals or immunosuppressives $[47,48]$.

The most commonly used method for highthroughput screening of antagonistic microorganisms against fungal pathogens in vitro is the dual culture assay [25]. However, streptomycetes are peculiar bacteria characterized by mycelial growth and particular life cycle, where the production of bioactive secondary metabolites is coordinated with the switch to the formation of aerial hyphae and spores [26, 28, 49]. Therefore, the aim of this work was to improve and adapt the dual culture assay for screening the antagonistic activity of

Table 3 In vitro (a) and in vivo (b) seed germination of cultivated rocket, lamb lettuce, lettuce and tomato untreated and treated with Streptomyces anulatus CMJ58I, S. albidoflavus VT111I and S. cyaneus ZEA171

\begin{tabular}{|c|c|c|c|c|c|}
\hline & \multirow{2}{*}{$\begin{array}{l}\text { Days of } \\
\text { incubation }\end{array}$} & \multicolumn{4}{|l|}{ Seed treatment } \\
\hline & & Untreated control & S. anulatus CMJ58I & S. albidoflavus VT1111 & S. cyaneus ZEA17I \\
\hline \multicolumn{6}{|c|}{ a) In vitro germination (\%) } \\
\hline Cultivated rocket & 6 & $84.3 \pm 4.63^{a} n s^{b}$ & $80.0 \pm 2.00 \mathrm{~ns}$ & $85.0 \pm 1.73 \mathrm{~ns}$ & $74.3 \pm 7.22 \mathrm{~ns}$ \\
\hline Lamb lettuce & 10 & $88.7 \pm 2.96 \mathrm{~ns}$ & $90.7 \pm 1.76 \mathrm{~ns}$ & $87.0 \pm 3.61 \mathrm{~ns}$ & $85.0 \pm 3.06 \mathrm{~ns}$ \\
\hline Lettuce & 7 & $79.7 \pm 2.85 \mathrm{~ns}$ & $78.3 \pm 2.40 \mathrm{~ns}$ & $81.7 \pm 1.86 \mathrm{~ns}$ & $84.3 \pm 1.86 \mathrm{~ns}$ \\
\hline Tomato & 8 & $95.0 \pm 1.53 \mathrm{~ns}$ & $96.0 \pm 1.15 \mathrm{~ns}$ & $96.3 \pm 2.19 \mathrm{~ns}$ & $96.7 \pm 1.33 \mathrm{~ns}$ \\
\hline \multicolumn{6}{|c|}{ b) In vivo germination (\%) } \\
\hline Cultivated rocket & 10 & $65.7 \pm 8.09 \mathrm{~ns}$ & $80.0 \pm 1.15 \mathrm{~ns}$ & $78.3 \pm 2.19 \mathrm{~ns}$ & $58.7 \pm 5.36 \mathrm{~ns}$ \\
\hline Lamb lettuce & 14 & $64.0 \pm 0.58 a$ & $58.7 \pm 4.06 \mathrm{a}$ & $33.0 \pm 6.43 b$ & $44.0 \pm 4.04 \mathrm{ab}$ \\
\hline Lettuce & 10 & $76.0 \pm 1.00 \mathrm{~ns}$ & $71.0 \pm 1.15 \mathrm{~ns}$ & $71.0 \pm 3.06 \mathrm{~ns}$ & $70.7 \pm 4.37 \mathrm{~ns}$ \\
\hline Tomato & 10 & $96.0 \pm 1.00 \mathrm{a}$ & $97.7 \pm 0.33 a$ & $92.0 \pm 2.52 \mathrm{ab}$ & $88.3 \pm 1.33 b$ \\
\hline
\end{tabular}

${ }^{a}$ mean value followed by standard error

b Tukey post-hoc test; mean values in a row with the same letters are not significantly different $(P=0.05)$; ns not significant 
Table 4 Effect of Streptomyces sp. on root and hypocotyl length of seedlings of cultivated rocket, lamb lettuce, lettuce and tomato in vitro

\begin{tabular}{|c|c|c|c|c|c|}
\hline & \multirow{2}{*}{$\begin{array}{l}\text { Length } \\
(\mathrm{mm})\end{array}$} & \multicolumn{4}{|l|}{ Seed treatment } \\
\hline & & Untreated control & S. anulatus CMJ58I & S. albidoflavus VT111। & S. cyaneus ZEA17I \\
\hline \multirow[t]{3}{*}{ Cultivated rocket } & Radicle & $15.52 \pm 1.00^{a} c^{b}$ & $46.83 \pm 2.11 \mathrm{a}$ & $31.11 \pm 1.79 b$ & $29.77 \pm 2.05 b$ \\
\hline & Hypocotyl & $9.34 \pm 0.31 b$ & $11.53 \pm 0.36 \mathrm{a}$ & $11.11 \pm 0.34 \mathrm{a}$ & $11.75 \pm 0.40 \mathrm{a}$ \\
\hline & $\mathrm{N}$ & 253 & 239 & 255 & 222 \\
\hline \multirow[t]{3}{*}{ Lamb lettuce } & Radicle & $16.79 \pm 0.51 b$ & $26.35 \pm 0.74 \mathrm{a}$ & $11.00 \pm 0.33 c$ & $9.08 \pm 0.42 c$ \\
\hline & Hypocotyl & $11.28 \pm 0.37 b$ & $14.55 \pm 0.34 \mathrm{a}$ & $10.41 \pm 0.30 \mathrm{bc}$ & $9.24 \pm 0.37 c$ \\
\hline & $\mathrm{N}$ & 266 & 272 & 261 & 255 \\
\hline \multirow[t]{3}{*}{ Lettuce } & Radicle & $16.33 \pm 0.68 d$ & $39.22 \pm 1.95 b$ & $28.31 \pm 1.50 c$ & $58.59 \pm 2.10 \mathrm{a}$ \\
\hline & Hypocotyl & $2.97 \pm 0.06 b$ & $2.77 \pm 0.05 b$ & $2.95 \pm 0.06 b$ & $3.51 \pm 0.06 \mathrm{a}$ \\
\hline & $N$ & 239 & 235 & 245 & 253 \\
\hline \multirow[t]{3}{*}{ Tomato } & Radicle & $54.17 \pm 1.09 b$ & $59.33 \pm 1.45 a$ & $63.96 \pm 1.55 \mathrm{a}$ & $63.41 \pm 1.00 \mathrm{a}$ \\
\hline & Hypocotyl & $11.52 \pm 0.26 c$ & $13.41 \pm 0.33 b$ & $14.69 \pm 0.32 \mathrm{a}$ & $14.79 \pm 0.29 a$ \\
\hline & $N$ & 285 & 288 & 289 & 290 \\
\hline
\end{tabular}

a The mean value followed by standard error

${ }^{\mathrm{b}}$ Tukey post-hoc test; mean values in a row with the same letters are not significantly different $(P=0.05)$; ns not significant

streptomycetes. We particularly considered the coordination of antibiotic production with the Streptomyces developmental program, similarly to Schrey et al. [28], who used the onset of Streptomyces sporulation as the time for fungus inoculation in co-culture. Moreover, we put the emphasis on the variable mycelium growth rate of the studied pathogens, so that we would be able to select a pool of strains showing a broad spectrum antagonistic activity against multiple fungal pathogens.

In the first step, we grouped the pathogens based on their mycelium growth rate into three groups and we tested the importance of pathogen growth rate and inoculation timing of both microorganisms in the dual culture assay. In the case of fast-growing fungi such as $S$. sclerotiorum we observed a significantly higher inhibition when Streptomyces was inoculated 2-3 days before the pathogen, which was not confirmed for slower growing fungi. This observation is in line with Schrey et al. [28] and confirms that Streptomyces start to produce the bioactive secondary metabolites later during their life cycle, and that, especially in the case of fast-growing pathogens, they need to be applied prior the pathogen inoculation, as we observed previously in vivo, where Streptomyces application 7 days before lettuce sowing significantly reduced Sclerotinia drop [9, 50].

The modified dual culture assay was applied to a collection of 130 streptomycetes and allowed us to compare the inhibition activity of individual Streptomyces strains

Table 5 Effect of Streptomyces sp. on plant dry weight of cultivated rocket, lamb lettuce, lettuce and tomato after 2 (a) and 3 (b) weeks of growth in vivo

\begin{tabular}{|c|c|c|c|c|}
\hline \multirow[t]{2}{*}{ Dry weight (mg) } & \multicolumn{4}{|l|}{ Seed treatment } \\
\hline & Untreated control & S. anulatus CMJ58I & S. albidoflavus VT1111 & S. cyaneus ZEA17I \\
\hline \multicolumn{5}{|l|}{ a) 2 weeks } \\
\hline Cultivated rocket & $5.13 \pm 0.31^{\mathrm{a}} n s^{\mathrm{b}}$ & $5.42 \pm 0.06 \mathrm{~ns}$ & $4.73 \pm 0.24 \mathrm{~ns}$ & $5.58 \pm 0.14 \mathrm{~ns}$ \\
\hline Lamb lettuce & $3.91 \pm 0.23 \mathrm{~ns}$ & $4.6 \pm 0.22 \mathrm{~ns}$ & $3.93 \pm 0.26 \mathrm{~ns}$ & $4.65 \pm 0.26 \mathrm{~ns}$ \\
\hline Lettuce & $3.32 \pm .25 \mathrm{~ns}$ & $3.16 \pm 0.12 \mathrm{~ns}$ & $3.14 \pm 0.18 \mathrm{~ns}$ & $3.66 \pm 0.16 \mathrm{~ns}$ \\
\hline Tomato & $5.58 \pm 0.08 \mathrm{ab}$ & $5.35 \pm 0.21 b$ & $4.95 \pm 0.48 b$ & $6.64 \pm 0.26 a$ \\
\hline \multicolumn{5}{|l|}{ b) 3 weeks } \\
\hline Cultivated rocket & $101.88 \pm 22.71 \mathrm{~ns}$ & $65.95 \pm 6.79 \mathrm{~ns}$ & $88.28 \pm 4.24 \mathrm{~ns}$ & $70.80 \pm 4.34 \mathrm{~ns}$ \\
\hline Lamb lettuce & $33.69 \pm 1.39 \mathrm{~ns}$ & $31.08 \pm 1.49 \mathrm{~ns}$ & $35.44 \pm 2.27 \mathrm{~ns}$ & $28.15 \pm 2.62 \mathrm{~ns}$ \\
\hline Lettuce & $76.02 \pm 4.48 \mathrm{ab}$ & $57.55 \pm 4.21 \mathrm{~b}$ & $79.37 \pm 5.77 \mathrm{a}$ & $77.62 \pm 5.91 \mathrm{a}$ \\
\hline Tomato & $43.62 \pm 6.35 \mathrm{~ns}$ & $48.38 \pm 5.15 \mathrm{~ns}$ & $56.47 \pm 4.31 \mathrm{~ns}$ & $45.58 \pm 6.93 \mathrm{~ns}$ \\
\hline
\end{tabular}

a The mean value followed by standard error. At 2 weeks (a) the mean value was calculated as the dry weight of 50 plantlets in three replicates, except for lamb lettuce, where 30 plantlets were collected. At 3 weeks (b) the mean value was calculated as the average dry weight of 20 individually grown plantlets

b Tukey post-hoc test; mean values in a row with the same letters are not significantly different $(P=0.05)$; ns not significant 
against six fungal soil borne pathogens. We selected three potential wide-spectrum bio-active strains, $S$. anulatus CMJ58I, S. albidoflavus VT111I and S. cyaneus ZEA17I, showing strong in vitro activity against all six pathogens. The results of the dual culture assay emphasized the antagonist-pathogen specific activity of individual Streptomyces strains. These results indicate that diverse streptomycetes use different antagonistic mechanisms and produce different bioactive molecules involved in the antagonism against different pathogens.

In order to develop strains showing biocontrol potential into commercial products, they need to be able to interact with the host to exert their activity in vivo [18]. Therefore, we studied the three selected streptomycetes for their ability to colonize various vegetable crops. The observations of seed surface by scanning electron microscopy revealed that all the three strains were able to grow on all tested hosts as early as 24 hai, as previously observed by Coombs and Franco [51] on wheat seeds inoculated with a Streptomyces sp. strain EN27. Moreover, S. cyaneus ZEA17I was observed on the surface and inside of 2-week-old lettuce roots by confocal and SEM microscopy [50]. Therefore, S. anulatus CMJ58I, S. albidoflavus VT111I and S. cyaneus ZEA17I are valuable candidates as beneficial bacteria for plant growth promotion and disease prevention.

It is also important that the potential BCAs do not affect negatively the germination and growth of the host plant. Among the variety of secondary metabolites, Streptomyces often produce IAA, which can improve the plant growth by stimulating cell elongation and root growth [18]. All the three tested strains produced IAA at high concentrations compared to previous studies [52], and the amount of IAA might be further increased in certain conditions [53]. Some authors observed improvement of plant growth by IAA-producing streptomycetes, for instance Streptomyces sp. CMUH009 promoted maize seed germination by $20 \%$ compared to control seeds treated with sterile water [54]. Similarly, the three strains, S. anulatus CMJ58I, S. albidoflavus VT111I and $S$. cyaneus ZEA17I, showed species-specific differences on germination and plant growth of cultivated rocket, lamb lettuce, lettuce and tomato. Although we did not detect significant differences on seed germination in vitro, inhibition of lamb lettuce and tomato germination was detected in vivo after the treatment with $S$. albidoflavus VT111I and S. cyaneus ZEA17I. This might have been due to the production of some secondary metabolites, as these two strains also reduced the growth of lamb lettuce radicles. Another possibility is that the complex interactions among the antagonist, the natural microflora and the host plant might have transiently negatively affected seed germination. Indeed, negative effects have been sometimes observed after application of
$\mathrm{BCAs}$ on the germination and plant growth in the absence of the pathogen [55]. However, this negative effect might be mitigated during the growth of the host plant, as we did not see any reduction in the biomass dry weight after bacterization by the three antagonists after 2 weeks of growth.

\section{Conclusion}

The standardized dual culture assay proposed in this work, in which the distance between the streptomycete and pathogen was set as a function of the mycelial growth of fungal pathogens, enabled us to compare the inhibition activity of candidate antagonistic bacteria against multiple pathogens showing different mycelial growth. The selected strains - S. anulatus CMJ58I, S. albidoflavus VT111I and S. cyaneus ZEA17I - showed species-specific effects on plant germination and growth. They only rarely negatively influenced plant growth, and these effects did not persist during the further development. Therefore, they are valuable candidates for the development as BCAs. However, further in vivo studies are needed to evaluate their potential as biological control or plant growth promoting agents.

\section{Methods \\ Streptomyces strains}

The strains were part of a collection of endophytic streptomycetes maintained in the laboratory of Plant Pathology at the Department of Food, Environmental and Nutritional Sciences (DeFENS), University of Milan, Italy [3]. Strains were grown on Czapek-Yeast Extract medium (CZY: 35 g/L Czapek Dox broth, Difco Laboratories, USA; $2 \mathrm{~g} / \mathrm{L}$ yeast extract, Difco Laboratories, USA; $15 \mathrm{~g} / \mathrm{L}$ agar, Applichem, Germany) for 3 weeks at $24{ }^{\circ} \mathrm{C}$. Spores were collected in $10 \%$ sterile glycerol + $0.01 \%$ tween 20 and filtered through two layers of sterile gauze. The concentration was determined and the spore suspension was stored at $-20{ }^{\circ} \mathrm{C}$.

\section{Pathogen strains}

The fungi and oomycetes used in this work are representatives of the main soil borne pathogens of horticultural crops. Sclerotinia sclerotiorum FW361, Fusarium oxysporum f.sp. lactucae L74, Thielaviopsis basicola FW406 and Pythium ultimum FW407 belong to a collection maintained in the laboratory of Plant Pathology at DeFENS, University of Milan, Italy. Two additional species, Rhizoctonia solani FW408 and Phytophthora sp. FW409, were kindly provided by Dr. Andrea Minuto (Centro di Sperimentazione e Assistenza Agricola, Albenga, Italy). The pathogens were maintained at $20{ }^{\circ} \mathrm{C}$ on Malt-Extract Agar medium (MEA: $30 \mathrm{~g} / \mathrm{L}$ malt extract, Difco Laboratories, USA; $15 \mathrm{~g} / \mathrm{L}$ agar, Applichem, Germany), whereas Phytophthora sp. FW409 on V8 
medium (200 mL/L V8 Vegetable juice, Campbell food, Belgium; $2 \mathrm{~g} / \mathrm{L} \mathrm{CaCO}_{3}$, Carlo Erba, Italy; $15 \mathrm{~g} / \mathrm{L}$ agar, Applichem, Germany).

\section{Pathogen mycelium growth curves}

The pathogen agar-mycelium disc (6 $\mathrm{mm}$ diameter), taken from the edge of an actively growing fungal colony, was inoculated upside down in the center of the Petri plate containing CZY or Potato Dextrose Agar medium (PDA: 39 g/L Potato Dextrose Agar, Difco Laboratories, USA) and plates were incubated at $24{ }^{\circ} \mathrm{C}$ in the dark. Four perpendicularly radial mycelium measurements were taken from the edge of the disc daily for 7 days in three replicates and the mean daily mycelial growth was calculated.

\section{Dual culture assay}

The antibiosis assay was performed in Petri plates (90 mm diameter) containing CZY medium for all fungi and oomycetes, except T. basicola FW406, for which PDA was used. The pathogen was inoculated as described above in the center of the Petri plate, whereas $10 \mu \mathrm{L}$ of streptomycete agar-spore suspension $(10 \mu \mathrm{L}$ of $10^{8} \mathrm{CFU} / \mathrm{mL}$ in $90 \mu \mathrm{L} 0.01 \%$ agar) were uniformly distributed along a $40 \mathrm{~mm}$ line. The two microorganisms were inoculated the same day at $20 \mathrm{~mm}$ and $10 \mathrm{~mm}$ distance for group 2- and 3-pathogens, respectively. For the group 1-pathogens, the streptomycetes were inoculated first, and the fungus was inoculated in the center of the plate 2 days after the streptomycete inoculation at $25 \mathrm{~mm}$ distance. Three replicates were prepared for each strain and plates inoculated only with the pathogen were used as control. Following the inoculation, plates were incubated at $24{ }^{\circ} \mathrm{C}$ in dark. The antagonistic activity was expressed as the percentage of mycelium growth inhibition compared to the control. It was calculated by the formula: $(\mathrm{R} 1-\mathrm{R} 2) / \mathrm{R} 1 \times 100$, where $\mathrm{R} 1$ and $\mathrm{R} 2$ were the mycelial radial growth of the pathogen in the control and in the presence of the antagonist, respectively.

In the preliminary study, the dual culture assays were performed in order to optimize the timing of inoculation of both microorganisms. Streptomyces rochei CMJ57I and S. anulatus CX14W were used as reference antagonist strains and S. sclerotiorum FW361 and F. oxysporum f.sp. lactucae L74 as representative pathogens. The antagonists were inoculated on CZY 3, 2 or 1 day before or at the same day as the pathogen and the percentage of inhibition was calculated at 3 and 7 days after pathogen inoculation, respectively.

\section{Selection of streptomycetes based on their antagonistic activity}

One hundred and thirty streptomycete strains were randomly chosen from the collection and their antagonistic activity against the six fungal soil borne pathogens was calculated as described above. The inhibition was assessed 3, 6 or 7 days after pathogen inoculation for group 1, 2 and 3, respectively. Subsequently, rank position was attributed to each streptomycete based on its inhibition activity against each pathogen (from 1 for the most active, to 130 for the least active) and for each strain the average of the six rank positions was calculated. The mean rank values were sorted from the smallest to the highest and the first three strains were chosen for the subsequent experiments (Table 2, Additional file 1: Table S1).

\section{Scanning electron microscope (SEM) studies of Streptomyces seed colonization}

The ability of three selected streptomycete strains (Streptomyces anulatus CMJ58I, S. albidoflavus VT111I and S. cyaneus ZEA17I) to colonize seed teguments was assessed under SEM (Leo Electron Microscopy, Cambridge, UK). Seeds of cultivated rocket (Eruca sativa Mill.; Fratelli Ingegnoli, Italy), lamb lettuce (Valerianella locusta L. 'Accent'; Enza Zaden, Italy), lettuce (Lactuca sativa L. 'Bionda ricciolina'; Fratelli Ingegnoli, Italy) and tomato (Solanum lycopersicum L. 'Marmande'; Fratelli Ingegnoli, Italy) were surface sterilized in $0.7 \%$ sodium hypochlorite for $5 \mathrm{~min}$ and rinsed three times in sterile water. Subsequently, they were immersed in $1 \mathrm{~mL}$ of streptomycete spore suspension $\left(10^{8} \mathrm{CFU} / \mathrm{mL}\right)$ and airdried under the laminar flow hood. Control seeds were treated with sterile water (untreated control). The seeds were then placed on moist filter paper in a Petri dish (20 cm in diameter) and were incubated at $20{ }^{\circ} \mathrm{C}$ in dark. Samples were freeze-dried 24, 48 and $72 \mathrm{~h}$ after seed inoculation as described previously $[56,57]$ and observed by SEM.

\section{Effects of streptomycetes on seed germination and seedling growth in vitro}

Three strains, Streptomyces anulatus CMJ58I, S. albidoflavus VT111I and S. cyaneus ZEA17I, were selected based on the results of the dual culture assay. Seeds of cultivated rocket (Eruca sativa Mill.), lamb lettuce (Valerianella locusta L. 'Accent'), lettuce (Lactuca sativa L. 'Bionda ricciolina') and tomato (Solanum lycopersicum L. 'Marmande') were surface sterilized as described above, immersed in a sufficient amount of Streptomyces spore suspension $\left(10^{8} \mathrm{CFU} / \mathrm{mL}\right)$ and air-dried under the laminar flow hood. Control seeds were treated with sterile water (untreated control). One hundred seeds were placed on moist filter paper in three replicates and incubated in the growth chamber at $24{ }^{\circ} \mathrm{C}, 55 \%$ relative humidity and $15 \mathrm{~h}$ photoperiod. During the experiment, filter paper was maintained humid adding a suitable volume of sterile water. Germination was assessed at 
different times based on vegetable species (Table 3) and the mean germination percentage was calculated. At the end of the experiment, which varied according to vegetable species, root and hypocotyl lengths were measured and the means were calculated.

\section{Effect of streptomycetes on plant biomass dry weight}

Seeds of cultivated rocket (Eruca sativa Mill.), lamb lettuce (Valerianella locusta L. 'Accent'), lettuce (Lactuca sativa L. 'Bionda ricciolina') and tomato (Solanum lycopersicum L. 'Marmande') were surface sterilized and bacterized with Streptomyces anulatus CMJ58I, $S$. albidoflavus VT111I or S. cyaneus ZEA17I as described above. Control seeds were treated with sterile water (untreated control). Two experiments were performed. In the first one, 100 seeds in three replicates for every combination plant species - Streptomyces were sown in the non-sterilized Irish and Baltic peat based growing substrate (Vigorplant, Italy) in plastic boxes $(10 \times 10 \times$ $10 \mathrm{~cm})$ and watered with tap water. The plants were grown in the growth chamber at $24{ }^{\circ} \mathrm{C}, 55 \%$ relative humidity and $15 \mathrm{~h}$ photoperiod and watered as necessary with tap water to keep the soil moist. The number of germinated plants was assessed after 10 days of growth for cultivated rocket, lettuce and tomato, and after 14 days for lamb lettuce. After 2 weeks (in case of cultivated rocket, lettuce and tomato) or 3 weeks in case of lamb lettuce, the plants were carefully removed from the boxes and the growing substrate was carefully removed from roots. Fifty plantlets were counted (except lamb lettuce, where 30 plantlets were counted), left to air-dry at room temperature and the biomass dry weight was determined.

In the second experiment, the bacterized seeds of four vegetable crops were placed individually in polystyrene seed trays $(48 \mathrm{~cm} 3 /$ cell) watered with tap water. The plants were grown in the growth chamber as described previously. After 3 weeks (except lamb lettuce, which was grown for 4 weeks), the plants were carefully removed from the seed trays and the growing substrate was carefully removed from roots. The plants were left to air-dry at room temperature and the biomass dry weight was determined.

\section{Production of compounds involved in plant growth promotion activity Indole-3-acetic acid (IAA)}

Ten $\mu \mathrm{L}$ of Streptomyces spore suspension were inoculated in $5 \mathrm{~mL}$ of Czapek broth added with $500 \mu \mathrm{g} / \mathrm{mL}$ of L-tryptophan (Sigma-Aldrich, USA). After 10 days of incubation at $26{ }^{\circ} \mathrm{C}$ with constant shaking at $125 \mathrm{rpm}$ in the dark, the production of IAA was determined as described previously [58].

\section{Siderophores}

Ten $\mu \mathrm{L}$ of Streptomyces agar-spore suspension were inoculated in the centre of a Petri plate (90 mm diameter), containing the Fe-free Czapek agar medium prepared as previously described [3]. After 14 days of incubation at $24{ }^{\circ} \mathrm{C}$ in the dark, the Streptomyces colony was overlaid by $15 \mathrm{~mL}$ of the chrome azurol S agar [59] as proposed by Pérez-Miranda et al. [60]. After 1 day of incubation at room temperature in the dark, the change of color around the colony (from blue to orange) indicated the siderophore production.

\section{Statistical analyses}

The statistical analyses were performed using $\mathrm{R}$ software, version R3.0.2 [61]. The percent data of inhibition activity and seed germination were arcsine root-square transformed and were submitted to ANOVA. Similarly, ANOVA was performed for data of root and hypocotyl lengths, and biomass dry weight, followed by a Tukey post-hoc test for multiple comparison $(P=0.05)$ using the TukeyC package [62].

\section{Additional file}

Additional file 1: Table S1. Mycelial growth inhibition of six soil borne pathogens by 130 Streptomyces strains. (DOCX $36 \mathrm{~kb}$ )

\section{Acknowledgements \\ The authors would like to thank to Elio Burrone for his help with dual culture assay and greenhouse experiments. \\ Funding \\ This research was in part supported by the research program "Dote ricerca applicata" funded by Lombardy Region and Sipcam Italia Spa.}

Availability of data and materials

All the data supporting the findings is contained within the manuscript or will be shared upon request.

\section{Authors' contributions}

$A K$ and $\mathrm{MB}$ performed the experiments, helped with the statistical analyses and wrote the manuscript. AK participated to the design of experiments. MS performed SEM sample preparation, observations and acquired SEM pictures. $C P$ helped with the in vivo experiments and conducted the statistical analyses. XC helped with the experiments and participated in discussion of experimental design. PC designed the outline of the study and partly supported the research. All authors read and approved the final manuscript.

\section{Competing interests}

The authors declare that the research was conducted in the absence of any commercial or financial relationships that could be construed as a potential conflict of interest.

\section{Consent for publication}

Not applicable.

Ethics approval and consent to participate

Not applicable.

Received: 16 April 2016 Accepted: 3 November 2016 Published online: 09 November 2016 


\section{References}

1. Seipke RF, Kaltenpoth M, Hutchings MI. Streptomyces as symbionts: an emerging and widespread theme? FEMS Microbiol Rev. 2012;36:862-76.

2. Loria R, Kers J, Joshi M. Evolution of plant pathogenicity in Streptomyces. Annu Rev Phytopathol. 2006;44:469-87.

3. Bonaldi M, Chen X, Kunova A, Pizzatti C, Saracchi M, Cortesi P. Colonization of lettuce rhizosphere and roots by tagged Streptomyces. Front Microbiol. 2015;6:25.

4. Cao L, Qiu Z, You J, Tan H, Zhou S. Isolation and characterization of endophytic streptomycete antagonists of fusarium wilt pathogen from surface-sterilized banana roots. FEMS Microbiol Lett. 2005;247:147-52. The Oxford University Press.

5. Coombs JT, Franco CMM. Isolation and identification of actinobacteria from surface-sterilized wheat roots. Appl Environ Microbiol. 2003;69:5603-8.

6. Sardi P, Saracchi M, Quaroni S, Petrolini B, Borgonovi GE, Merli S. Isolation of endophytic Streptomyces strains from surface-sterilized roots. Appl Environ Microbiol. 1992:58:2691-3.

7. Dombou CL, Salove MKH, Crawford DL, Beaulieu C. Actinomycetes, promising tools to control plant diseases and to promote plant growth. Phytoprotection. 2001;82:85-102.

8. Palaniyandi SA, Yang SH, Zhang L, Suh JW. Effects of actinobacteria on plant disease suppression and growth promotion. Appl Microbiol Biotechnol. 2013:97:9621-36.

9. Bonaldi M, Kunova A, Saracchi M, Sardi P, Cortesi P. Streptomycetes as biological control agents against basal drop. Acta Hortic ISHS. 2014;1044: 313-8.

10. El-Tarabily KA, Soliman MH, Nassar AH, Al-Hassani HA, Sivasithamparam K, McKenna F, et al. Biological control of Sclerotinia minor using a chitinolytic bacterium and actinomycetes. Plant Pathol. 2000;49:573-83.

11. Faheem M, Raza W, Zhong W, Nan Z, Shen Q, Xu Y. Evaluation of the biocontrol potential of Streptomyces goshikiensis YCXU against Fusarium oxysporum f. sp. niveum. Biol Control. 2015:81:101-10.

12. Kanini GS, Katsifas EA, Savvides AL, Karagouni AD. Streptomyces rochei ACTA1551, an indigenous greek isolate studied as a potential biocontrol agent against Fusarium oxysporum f.sp. lycopersici. Biomed Res Int. 2013; 2013:10, 387230. doi:10.1155/2013/387230

13. Xiao K, Kinkel LL, Samac DA. Biological control of Phytophthora root rots on alfalfa and soybean with Streptomyces. Biol. Control. 2002;23:285-95.

14. Conn VM, Walker AR, Franco CMM. Endophytic actinobacteria induce defense pathways in Arabidopsis thaliana. Mol Plant Microbe Interact. 2008; 21:208-18.

15. Lehr NA, Schrey SD, Hampp R, Tarkka MT. Root inoculation with a forest soil streptomycete leads to locally and systemically increased resistance against phytopathogens in Norway spruce. New Phytol. 2008;177:965-76.

16. Kurth F, Mailänder S, Bönn M, Feldhahn L, Herrmann S, Große I, et al. Streptomyces-induced resistance against oak powdery mildew involves host plant responses in defense, photosynthesis, and secondary metabolism pathways. Mol Plant Microbe Interact. 2014;27:891-900.

17. Nassar AH, El-Tarabily KA, Sivasithamparam K. Growth promotion of bean (Phaseolus vulgaris L.) by a polyamine-producing isolate of Streptomyces griseoluteus. Plant Growth Regul. 2003:40:97-106. Kluwer Academic Publishers.

18. El-Tarabily KA. Promotion of tomato (Lycopersicon esculentum Mill.) plant growth by rhizosphere competent 1-aminocyclopropane-1-carboxylic acid deaminase-producing streptomycete actinomycetes. Plant Soil. 2008;308: 161-74.

19. Sadeghi A, Karimi E, Dahaji PA, Javid MG, Dalvand Y, Askari H. Plant growth promoting activity of an auxin and siderophore producing isolate of Streptomyces under saline soil conditions. World J Microbiol Biotechnol. 2012;28:1503-9.

20. Gopalakrishnan S, Vadlamudi S, Bandikinda P, Sathya A, Vijayabharathi R, Rupela $\mathrm{O}$, et al. Evaluation of Streptomyces strains isolated from herbal vermicompost for their plant growth-promotion traits in rice. Microbiol Res. 2014;169:40-8

21. Duca D, Lorv J, Patten CL, Rose D, Glick BR. Indole-3-acetic acid in plantmicrobe interactions. Antonie Van Leeuwenhoek. 2014;106:85-125.

22. Gopalakrishnan S, Srinivas V, Alekhya G, Prakash B. Effect of plant growthpromoting Streptomyces sp. on growth promotion and grain yield in chickpea (Cicer arietinum L). 3 Biotech. 2015;5:799-806.

23. Tokala RK, Strap JL, Jung CM, Crawford DL, Salove MH, Deobald LA, et al, Novel plant-microbe rhizosphere interaction involving Streptomyces lydicus
WYEC108 and the Pea plant (Pisum sativum). Appl Environ Microbiol. 2002; 68:2161-71.

24. Watve MG, Tickoo R, Jog MM, Bhole BD. How many antibiotics are produced by the genus Streptomyces? Arch. Microbiol. 2001;176:386-90.

25. Pliego C, Ramos C, de Vicente A, Cazorla FM. Screening for candidate bacterial biocontrol agents against soilborne fungal plant pathogens. Plant Soil. 2011;340:505-20.

26. Chater KF. Streptomyces inside-out: a new perspective on the bacteria that provide us with antibiotics. Philos Trans R Soc Lond B Biol Sci. 2006;361: 761-8.

27. Hopwood DA. The Leeuwenhoek Lecture, 1987: Towards an understanding of gene switching in Streptomyces, the basis of sporulation and antibiotic production. Proc R Soc B, Biol Sci. 1988;235:121-38.

28. Schrey SD, Erkenbrack E, Früh E, Fengler S, Hommel K, Horlacher N, et al. Production of fungal and bacterial growth modulating secondary metabolites is widespread among mycorrhiza-associated streptomycetes. BMC Microbiol. 2012;12:164

29. Boukaew S, Chuenchit S, Petcharat V. Evaluation of Streptomyces spp. for biological control of Sclerotium root and stem rot and Ralstonia wilt of chili pepper. BioControl. 2011;56:365-74.

30. Chamberlain $\mathrm{K}$, Crawford DL. In vitro and in vivo antagonism of pathogenic turfgrass fungi by Streptomyces hygroscopicus strains YCED9 and WYE53. J Ind Microbiol Biotechnol. 1999;23:641-6.

31. Trejo-Estrada SR, Sepulveda IR, Crawford DL. In vitro and in vivo antagonism of Streptomyces violaceusniger YCED9 against fungal pathogens of turfgrass. World J Microbiol Biotechnol. 1998;14:865-72. Kluwer Academic Publishers.

32. Ji SH, Gururani MA, Chun SC. Isolation and characterization of plant growth promoting endophytic diazotrophic bacteria from Korean rice cultivars. Microbiol Res Elsevier GmbH. 2014;169:83-98.

33. Jog R, Nareshkumar G, Rajkumar S. Plant growth promoting potential and soil enzyme production of the most abundant Streptomyces spp. from wheat rhizosphere. J Appl Microbiol. 2012;113:1154-64.

34. Rungin S, Indananda C, Suttiviriya P, Kruasuwan W, Jaemsaeng R, Thamchaipenet A. Plant growth enhancing effects by a siderophoreproducing endophytic streptomycete isolated from a Thai jasmine rice plant (Oryza sativa L. cv. KDML105). Antonie Van Leeuwenhoek. 2012;102:463-72.

35. Lugtenberg B, Kamilova F. Plant-growth-promoting rhizobacteria. Annu Rev Microbiol Annual Reviews. 2009:63:541-56.

36. Lugtenberg BJ, Dekkers L, Bloemberg GV. Molecular determinants of rhizosphere colonization by Pseudomonas. Annu Rev Phytopathol. 2001;39: 461-90.

37. Verma VC, Singh SK, Prakash S. Bio-control and plant growth promotion potential of siderophore producing endophytic Streptomyces from Azadirachta indica A. Juss J Basic Microbiol. 2011;51:550-6.

38. Berg G. Plant-microbe interactions promoting plant growth and health: Perspectives for controlled use of microorganisms in agriculture. Appl Microbiol Biotechnol. 2009:84:11-8.

39. Expert D, Franza T, Dellagi A. Iron in plant-pathogen interactions. In: Expert D, O'Brian MR, editors. Mol. Asp. Iron Metab. Pathog. Symbiotic PlantMicrobe Assoc. Netherlands: Springer; 2012. p. 7-39.

40. Beneduzi A, Ambrosini A, Passaglia LMP. Plant growth-promoting rhizobacteria (PGPR): Their potential as antagonists and biocontrol agents. Genet Mol Biol. 2012:35:1044-51.

41. Sharma A, Johri B, Sharma A, Glick B. Plant growth-promoting bacterium Pseudomonas sp. strain GRP3 influences iron acquisition in mung bean (Vigna radiata L. Wilzeck). Soil Biol Biochem. 2003;35:887-94.

42. Audenaert K, Pattery T, Cornelis $P$, Höfte $M$. Induction of systemic resistance to Botrytis cinerea in tomato by Pseudomonas aeruginosa 7NSK2: role of salicylic acid, pyochelin, and pyocyanin. Mol Plant Microbe Interact. 2002;15: $1147-56$

43. Murao S, Hayashi H. Gougerotin, as a plant growth inhibitor, from Streptomyces sp. No. 179. Agric Biol Chem. 1983:47:1135-6.

44. Heisey RM, Putnam AR. Herbicidal effects of geldanamycin and nigericin, antibiotics from Streptomyces hygroscopicus. J Nat Prod. 1986:49:859-65.

45. Babalola OO. Beneficial bacteria of agricultural importance. Biotechnol. Lett. 2010:32:1559-70.

46. Cao L, Qiu Z, You J, Tan H, Zhou S. Isolation and characterization of endophytic Streptomyces strains from surface-sterilized tomato (Lycopersicon esculentum) roots. Lett Appl Microbiol. 2004;39:425-30.

47. Lucas X, Senger C, Erxleben A, Grüning BA, Döring K, Mosch J, et al. StreptomeDB: A resource for natural compounds isolated from Streptomyces 
species. Nucleic Acids Res. 2013; 41(Database issue):D1130-6. doi: 10.1093/ nar/gks1253.41

48. de Lima Procópio RE, da Silva IR, Martins MK, de Azevedo JL, de Araújo JM. Antibiotics produced by Streptomyces. Braz J Infect Dis. 2012;16:466-71.

49. Flärdh K, Buttner MJ. Streptomyces morphogenetics: dissecting differentiation in a filamentous bacterium. Nat Rev Microbiol. 2009;7:36-49.

50. Chen X, Pizzatti C, Bonaldi M, Saracchi M, Erlacher A, Kunova A, et al. Biological control of lettuce drop and host plant colonization by rhizospheric and endophytic streptomycetes. Front Microbiol. 2016;7:714.

51. Coombs JT, Franco CMM. Visualization of an endophytic Streptomyces species in wheat seed. Appl Environ Microbiol. 2003;69:4260-2.

52. Abd-alla MH, El-Sayed AE-S, Rasmey A-HM. Indole-3-acetic acid (IAA) production by Streptomyces atrovirens isolated from rhizospheric soil in Egypt. J Biol Earth Sci. 2013;3:B182-93.

53. Harikrishnan H, Shanmugaiah V, Balasubramanian N. Optimization for production of Indole acetic acid (IAA) by plant growth promoting Streptomyces sp VSMGT1014 isolated from rice rhizosphere. Int J Curr Microbiol Appl Sci. 2014;3:158-71.

54. Khamna S, Yokota A, Peberdy JF. Indole-3-acetic acid production by Streptomyces sp. isolated from some Thai medicinal plant rhizosphere soils. EurAsian J Biosci. 2010;4:23-32.

55. Koch E. Effect of biocontrol agents on plant growth in the absence of pathogens. IOBC/WPRS Bull. 2001;24:81-9.

56. Assante G, Saracchi M, Farina G, Moricca S. Histological studies on the mycoparasitism of Clamidosporium tenuissimum on urediospores of Uromyces appendiculatus. Mycol Res. 1992;17:170-82.

57. Rocchi F, Quaroni S, Sardi P, Saracchi M. Studies on Anthostoma decipiens involved in Carpinus betulus decline. J Plant Pathol. 2010;92:637-44.

58. Bano N, Musarrat J. Characterization of a new Pseudomonas aeruginosa strain NJ-15 as a potential biocontrol agent. Curr Microbiol. 2003;46:324-8.

59. Schwyn B, Neilands JB. Universal chemical assay for the detection and determination of siderophores. Anal Biochem. 1987;160:47-56.

60. Pérez-Miranda S, Cabirol N, George-Téllez R, Zamudio-Rivera LS, Fernández FJ. O-CAS, a fast and universal method for siderophore detection. J Microbiol Methods. 2007;70:127-31.

61. R_Core_Team. R: A language and environment for statistical computing. Vienna: The R Foundation for Statistical Computing; 2013.

62. Faria JC, Jelihovschi EG, Allaman IB. Conventinal Tukey Test. Ilheus: Universidade Estadual de Santa Cruz; 2014.

\section{Submit your next manuscript to BioMed Central and we will help you at every step:}

- We accept pre-submission inquiries

- Our selector tool helps you to find the most relevant journal

- We provide round the clock customer support

- Convenient online submission

- Thorough peer review

- Inclusion in PubMed and all major indexing services

- Maximum visibility for your research

Submit your manuscript at www.biomedcentral.com/submit 